\title{
TICAGRELOR ALLEVIATES SEPSIS-INDUCED MYOCARDIAL INJURY VIA AN ADENOSINE-DEPENDENT PATHWAY IN A MOUSE SEPSIS MODEL
}

\author{
VOL 43 NO 4 DECEMBER 2020
}

\author{
Shengxing Tang, $\mathrm{PhD}^{1,}$, Cong Fu, $\mathrm{PhD}^{1,2,}$, Qiancheng $\mathrm{Xu}, \mathrm{MD}^{3, *}$, Wenjun Guo, $\mathrm{PhD}{ }^{4,5}$, Yuhan Cao, $\mathrm{PhD}^{6,2}$ \\ 1 Department of Cardiology, Yi Ji Shan Hospital affiliated to Wan Nan Medical College, Wuhu, China \\ 2 Key Laboratory of Non-coding RNA Transformation Research of Anhui Higher Education Institution (Wan Nan Medical College), Wuhu, China \\ 3 Department of Critical Care Medicine, Yi Ji Shan Hospital affiliated to Wan Nan Medical College, Wuhu, China \\ 4 Perioperative Medicine Molecular Laboratory, Wan Nan Medical College, Wuhu, China \\ 5 Department of Anesthesiology, Yi Ji Shan Hospital affiliated to Wan Nan Medical College, Wuhu, China \\ 6 Department of Nephrology, Yi Ji Shan Hospital affiliated to Wan Nan Medical College, Wuhu, China \\ *These authors contributed equally to this work
}

Submitted 7th June 2020, Accepted 9th September 2020

Clin Invest Med. 2020;43(4):E44-55. DOI: 10.25011/cim.v43i4.34775

\section{ABSTRACT}

Purpose: The purpose of this study was to determine whether ticagrelor, a classic anti-platelet drug, has a therapeutic effect on sepsis-induced myocardial injury.

Methods: The C57BL6) mice received oral ticagrelor (10, 25 and $50 \mathrm{mg} / \mathrm{kg}$ ) for seven days after which cecum ligation and puncture (CLP) were performed. An adenosine-receptor antagonist (CGS15943) was administered two hours before CLP. After $24 \mathrm{~h}$, cardiac function was measured using cardiac echocardiography, then the heart and blood were collected. Hematoxylin and eosin (HE) staining and terminal deoxynucleotidyl transferase dUTP nick end labelling (TUNEL staining) were used to observe pathological changes and cardiomyocyte apoptosis. Plasma concentration of TNF- $\alpha$, IL- 6 and adenosine and myocardial tissue levels of TNF- $\alpha$ and IL- 6 were determined. Survival analysis was performed. Western blot was used to determine the expression of a signalling protein in the myocardial tissue.

Results: The HE and TUNEL staining showed less inflammatory cell infiltration and less cardiomyocyte apoptosis in the ticagrelor group. Cardiac echocardiography showed preserved heart function in the ticagrelor group. Plasma TNF- $\alpha$, IL- 6 and relative expression of TNF- $\alpha$ and IL- 6 in myocardial tissue were significantly lower in the ticagrelor group. Plasma adenosine levels were significantly higher in the ticagrelor group. Adenosine-receptor antagonists significantly blocked the protective effect of ticagrelor. Ticagrelor reduced the mortality of sepsis mice, and this reduction was blocked by the adenosine-receptor antagonist. Western blot showed that ticagrelor activated the phosphorylation of AKT and mTOR. Adenosine-receptor antagonists inhibited the activation of AKT and mTOR.

Conclusion: The protective effect of ticagrelor was dependent on adenosine-receptor activation, with downstream upregulation of phosphorylation of AKT and mTOR.

Correspondence to: Yuhan Cao, cyh880130@163.com

\section{INTRODUCTION}

Sepsis is a life-threatening organ dysfunction caused by a dysregulated host response to infection [1]. Myocardial injury is a common complication of sepsis, and leads to high mortality levels. A previous study indicated that the inflammatory reaction played a role in sepsis-induced myocardial damage [2].

The role of antiplatelet drug, ticagrelor, in non-throm- botic diseases has been studied. A previous study suggested that ticagrelor reduced the plasma level of inflammatory factors in patients with pneumonia [3]. In sepsis-induced acute kidney injury, ticagrelor has been shown to protect renal function by inhibiting inflammation, recruitment of neutrophils into the kidney and cell apoptosis in renal tissue [4]. Ticagrelor inhibits the platelet P2Y12 receptor, a type of ADP receptor, to block the prothrombotic effects of platelets [5]. Ticagrelor can 
increase the level of adenosine by inhibiting the intracellular adenosine re-uptake that may lead to dyspnea [6-8]. The protecting effect of ticagrelor was found to be correlated with adenosine levels [9]. Previous studies showed that adenosine has a cardiac protecting effect; inhibiting cardiomyocytes apoptosis and alleviating ischemic injury. The A1 receptor is the key regulator of this cardiac protecting effect of adenosine [10].

Whether ticagrelor inhibits myocardial injury in sepsis needs to be studied further. We hypothesized that ticagrelor can alleviate sepsis-induced myocardial injury via an adenosine-dependent pathway. Specifically, we designed this study to determine if ticagrelor alleviates inflammatory reaction and myocardial apoptosis via adenosine, and to identify the potential signal pathway(s).

\section{MATERIAL AND METHODS}

\section{Mouse sepsis model}

Sepsis model was performed using C57BL/6J mice (8-10 weeks old, weight: 20-25 g) via cecum ligation and puncture (CLP) as described previously [11]. Briefly, mice were anesthetized intraperitoneally with $1 \%$ pentobarbital (Sigma, USA, $35 \mathrm{mg} / \mathrm{kg}$ ). The cecum was ligated with a 5.0 silk suture at its base and then punctured once with a 21-gauge needle. The cecum was re-inserted into the abdominal cavity and the peritoneal wall and skin incision were sutured. Sham group mice underwent a similar surgery without ligation or puncture.

Before the CLP surgery, mice $(n=35)$ received oral ticagrelor (10, 25 and $50 \mathrm{mg} / \mathrm{kg}$, respectively, one time per $24 \mathrm{~h}$, for seven days (AstraZeneca, UK) as described previously [3]. The adenosine-receptor antagonist, CGS15943 (Sig$\mathrm{ma}$, USA), was administered (10 $\mathrm{mg} / \mathrm{kg}$, intraperitoneal injection) to block the adenosine pathway $2 \mathrm{~h}$ before CLP according to previous research [12]. The mice were randomly divided into seven groups: control non-operated (control, $n=5)$, control operated ( $\operatorname{cham}, n=5)$, sepsis $(n=5)$, sepsis+10 mg/kg ( $=5)$, sepsis+25 mg/kg ( $=5)$, sepsis+50 $\mathrm{mg} / \mathrm{kg}(\mathrm{n}=5)$ and adenosine-receptor antagonist group (sepsis+50 mg/kg+CGS15943, n=5). All mice received $1 \mathrm{ml}$ of sterile saline subcutaneously after surgery. No antibiotics or anti-inflammatory drugs were administered. After $24 \mathrm{~h}$ of the surgery, all mice were sacrificed under deep anesthesia with overdose $(130 \mathrm{mg} / \mathrm{kg}$ intraperitoneal injection) pentobarbital (Sigma) and the intact hearts and blood samples were collected.

\section{Echocardiography}

After the sepsis model established (24 h), 2-dimensional echocardiography was performed on the mice using a transthoracic echocardiogram (Visual Sonic, Canada) as previously described [13]. The echocardiography images were obtained by an operator blinded to groups. The left ventricular ejection fraction (LVEF), left ventricular internal dimension-end-systolic (LVIDd), left ventricular internal dimension-end-diastolic (LVIDs) and left ventricular fractional shortening (LVFS) were calculated by a technician blinded to groups.

\section{Enzyme-linked immunosorbent assay}

Mouse blood was collected into an EDTA-coated tube. After centrifugation at $500 \mathrm{~g}$ for $20 \mathrm{~min}$, plasma was collected. Plasma concentrations of IL- 6 and TNF- $\alpha$ were measured using Mouse IL-6 Quantikine enzyme-linked immunosorbent assay (ELISA) and mouse TNF- $\alpha$ Quantikine ELISA kits (R\&D Systems, USA) according to the manufacturer's protocols.

\section{High-performance liquid chromatography}

The plasma concentration of adenosine was measured using high-performance liquid chromatography (HPLC) as previously published [12]. Briefly, 20 uL plasma was collected and $5 \mu \mathrm{L}$ of chloroacetaldehyde was added. The tubes were capped, mixed and submerged in a boiling water bath for $10 \mathrm{~min}$. Samples were analyzed by HPLC using a Waters C18 reversed phase $150 \mathrm{~mm} \mathrm{x}$ $4.6 \mathrm{~mm}$ column. The mobile phase was a $50 \mathrm{mM}$ acetate buffer ( $\mathrm{pH} 4.5)$ and $6.5 \%$ aqueous acetonitrile (volume/ volume) containing $2 \mathrm{mM}$ sodium octyl sulfonate, flow rate was $1.1 \mathrm{~mL} / \mathrm{min}$, the excitation monochromator was set to a wavelength of $270 \mathrm{~nm}$ and the cutoff wavelength of the emission filter was $389 \mathrm{~nm}$.

\section{Reverse transcription polymerase chain reaction}

Each mouse heart was stored in Trizol at $-80^{\circ} \mathrm{C}$. Total RNA was extracted according to the manufacturer's protocol (Ambion, Life Technologies, USA). Furthermore, the concentration and purity of RNA were assessed using the relative absorbance ratio at 260/280 in a NanoDrop 2000 (Thermo, USA). The GAPDH RNA was measured as a control. The cDNA was synthesized using PrimeScript ${ }^{\mathrm{TM}}$ reverse transcription (RT) reagent kit with gDNA Eraser (Takara, Japan). The reverse transcription polymerase chain reaction (RT-PCR) was performed using the following primers:

IL-6 (forward: CTGCAAGAGACTTCCATCCAG, reverse: AGTGGTATAGACAGGTCTGTTGG); TNF- $\alpha$ primers (forward: CAGGCGGTGCCTATGTCTC, reverse: CGATCACCCCGAAGTTCAGTAG); and GAPDH (forward: AATGGATTTGGACGCATTGGT, reverse: TTTGCACTGGTACGTGTTGAT).

After RT $\left(50^{\circ} \mathrm{C}, 30 \mathrm{~min}\right)$, hot start $\left(94^{\circ} \mathrm{C}, 15 \mathrm{~min}\right)$ and 40-42 cycles of PCR $\left(94^{\circ} \mathrm{C}, 1 \mathrm{~min} ; 52.5^{\circ} \mathrm{C}, 1 \mathrm{~min} ; 72^{\circ} \mathrm{C}, 1\right.$ $\mathrm{min})$, IL- 6 and TNF- $\alpha$ mRNA expression was determined, normalized to GAPDH and calculated as $2^{-\Delta \Delta c t}$. 


\section{Cardiac histopathology}

The heart tissue was fixed in $10 \%$ formaldehyde, and then embedded in paraffin. Tissue sections ( $2 \mu \mathrm{M}$ thick) were stained with hematoxylin and eosin (HE) using a HE Staining Kit (Beyotime, China) according to the manufacturer's protocol. Morphological changes of myocardial tissue were assessed using an optical microscope (Olympus, Japan). Five heart tissue sections per mouse were stained with $\mathrm{HE}$. Five random 400X fields per HE staining sections were selected to calculate heart injury score. There were two independent pathologists blinded to the groups to complete the analysis of the HE staining image. The morphological evaluations were performed by two independent pathologists blinded to the treatment group. The heart injury score was calculated as previously described [14,15].

\section{TUNEL immunohistochemistry}

Terminal deoxynucleotidyl transferase-mediated dUTP nick end labelling (TUNEL) staining was performed to detect apoptotic nuclei by TUNEL staining kit (Roche, USA) according to the manufacturer's protocol. Five heart tissue sections per mouse were stained with TUNEL. Five random 400X fields per section were selected and averaged to calculate apoptotic cell numbers. Evaluations of the TUNEL staining images were performed by two independent pathologists blinded to the treatment group.

\section{Survival analysis}

The CLP model and drug treatment were performed as described above (an additional $n=10$ for each group). The mice were housed in a specific-pathogen-free animal facility without any antibacterial therapy for 10 days. The mortality of each group was determined.

\section{Western blot}

Protein was extracted from mouse myocardial tissue using a tissue protein extraction kit (Beyotime) according to the manufacturer's protocol. Protein concentrations were measured using the BCA Assay Kit (Pierce, USA). Western blots of the protein samples were performed to detect the mammalian target of rapamycin (mTOR) and phosphorylated Ser ${ }^{2448}$-mTOR (P-Ser ${ }^{2448}$ mTOR) using rabbit monoclonal anti-mouse $\mathrm{mTOR}$ antibodies and the rabbit monoclonal anti-mouse phosphorylated Ser ${ }^{2448}$. mTOR antibody (Cell Signaling Technology, USA). Rabbit monoclonal anti-mouse AKT antibodies, rabbit monoclonal anti-mouse phosphorylated Ser ${ }^{473}$ AKT (P-Ser ${ }^{473}$ AKT) (Cell Signaling Technology) antibody was used to detect AKT and P-Ser ${ }^{473}$ AKT. The GAPDH was used as a loading control (KangCheng Biotech, China). Horseradish peroxidase-conjugated goat anti-rabbit secondary antibody was obtained from Boster (China).

\section{Statistical analyses}

For all experiments, normal distribution and equal variances data were compared using one-way analysis of variance (ANOVA). Multiple comparison was performed using Bonferroni's test. One-way ANOVA and Bonferroni's test were used to compare the score of histological damage, TUNEL-positive cells, cardiac function (LVEF, LVFS, LVIDd and LVIDs), plasma concentration of IL-6, TNF- $\alpha$ and adenosine and heart injury score among the seven groups (control, sham, sepsis, ticagrelor $10 \mathrm{mg} / \mathrm{kg}$, ticagrelor $25 \mathrm{mg} / \mathrm{kg}$, ticagrelor $50 \mathrm{mg} / \mathrm{kg}$ and ticagrelor $50 \mathrm{mg} / \mathrm{kg}+\mathrm{CGS} 1594310 \mathrm{mg} / \mathrm{kg}$ ). The continuous variable was expressed as the means \pm SD. A Kruskal-Wallis test was used for variance inequality or non-normal distribution data (IL- 6 and TNF- $\alpha$ mRNA expression in kidney tissue) among the seven groups. The AKT, P-AKT, mTOR and P-mTOR protein expression were compared by Kruskal-Wallis test among the seven groups. Survival analysis was performed using Kaplan-Meier analysis. All statistical analyses were performed using SPSS 17.0 software (SAS Institute, USA); $p$ values $<0.05$ were considered to indicate significance.

\section{RESULTS}

Effect of ticagrelor administration on sepsis-induced myocardial injury

The HE staining showed myocardial lysis, myocardial hemorrhage and interstitial edema in the sepsis group compared with the control and sham groups. In the ticagrelor group, the myocardial injury was significantly alleviated and dependent on the dose of ticagrelor administered. The adenosine-receptor antagonist (CGS15943) inhibited the protective effect of ticagrelor. The calculated heart injury score was higher in the sepsis group than the control group. Ticagrelor treatment decreased the heart injury score and CGS15943 reversed the effect of ticagrelor ( $14.0 \pm 2.0$ in sepsis vs $1.0 \pm 0.2$ in control, mean difference: $13.0, \mathrm{~F}=64.603, p<0.001$, df=6; $6.0 \pm 1.0$ in ticagrelor $50 \mathrm{mg} / \mathrm{kg}$ vs sepsis, mean difference: -8.0, $\mathrm{F}=64.603, p<0.001, \mathrm{df}=6$ ) (Figure 1). The TUNEL staining showed that apoptotic cardiomyocytes increased markedly in the myocardium tissue in the sepsis group compared with the control and sham groups (71.7 $\pm 4.6 /$ field vs $8.3 \pm 3.4$ /field, mean difference: 63.3 , $F=180.667$, $p<0.001, \mathrm{df}=6 ; 71.7 \pm 4.6 /$ field vs $7.4 \pm 2.9 /$ field, mean difference: $64.3, \mathrm{~F}=180.667, p<0.001, \mathrm{df}=6$, respectively). However, apoptotic cardiomyocytes decreased in the ticagrelor groups compared with the sepsis group and the ticagrelor showed a dose-dependent protecting effect $(43.0 \pm 4.1 /$ field in $10 \mathrm{mg} / \mathrm{kg}$ ticagrelor vs $71.7 \pm 4.6 /$ field in sepsis, mean difference: $-28.7, F=180.667, p<0.001$, $\mathrm{df}=6 ; 35.0 \pm 5.3$ in $25 \mathrm{mg} / \mathrm{kg}$ vs $71.7 \pm 4.6 /$ field in sepsis, mean difference: $-36.7, F=180.667, p<0.001, d f=6 ; 20.1 \pm 2.3 /$ field in $50 \mathrm{mg} / \mathrm{kg}$ vs $71.7 \pm 4.6 /$ field in sepsis, mean differ- 
FIGURE 1.

EFFECT OF TICAGRELOR AND ANTAGONIST ON MYOCARDIAL TISSUE.

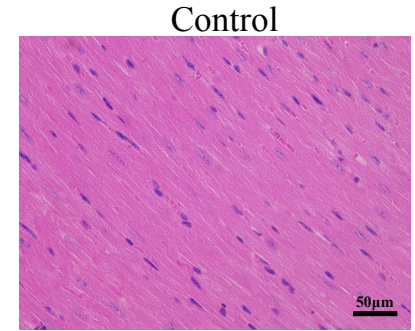

Ticagrelor $10 \mathrm{mg} / \mathrm{kg}$

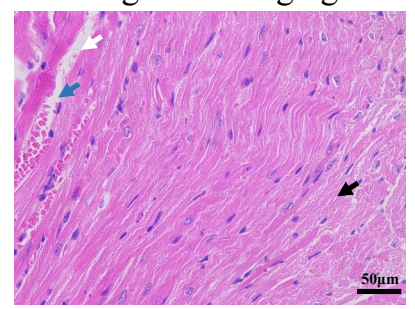

Sham

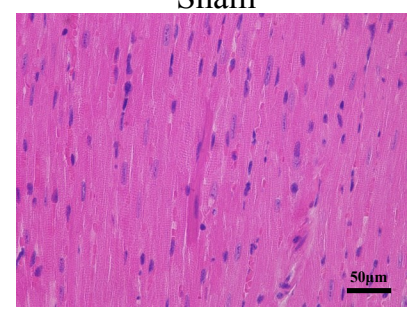

Ticagrelor $25 \mathrm{mg} / \mathrm{kg}$

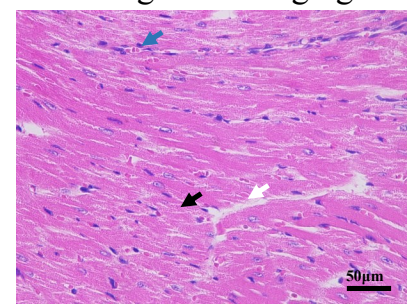

Sepsis

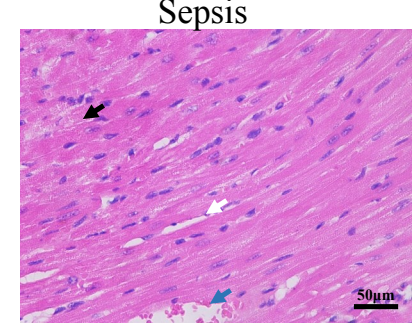

Ticagrelor $50 \mathrm{mg} / \mathrm{kg}$

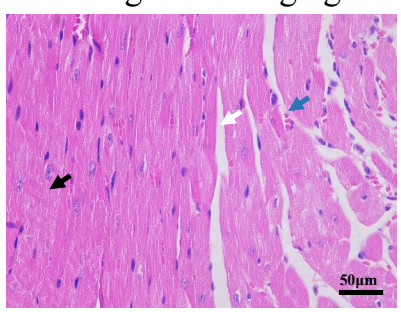

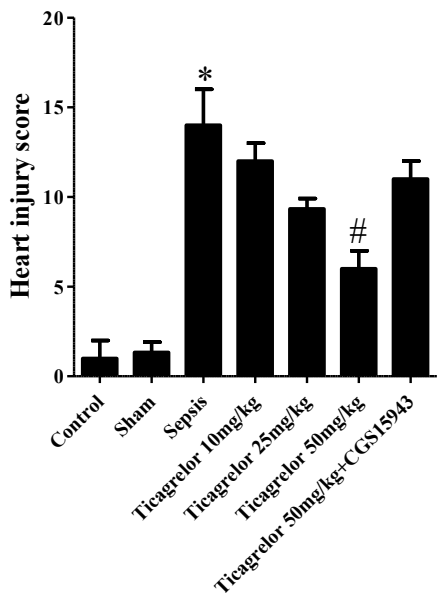

Ticagrelor $50 \mathrm{mg} / \mathrm{kg}+\mathrm{CGS} 1594310 \mathrm{mg} / \mathrm{kg}$

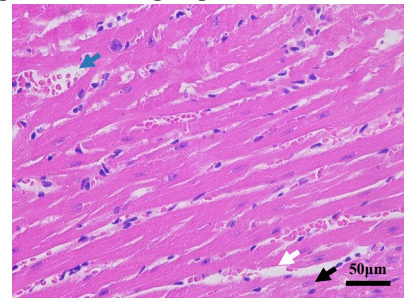

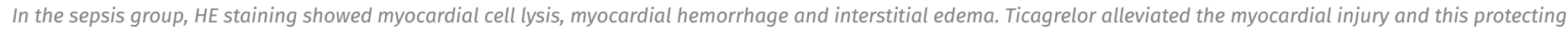

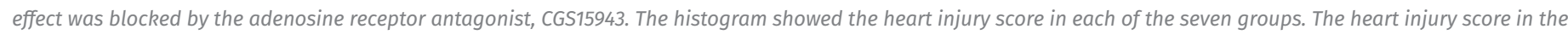

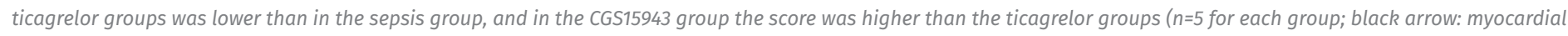
cell lysis, white arrow: interstitial edema, blue arrow: myocardial hemorrhage. ${ }^{\star} p<0.001$ vs control and sham, \#p<0.001 vs sepsis; magnification: $400 x$ ).

ence: $-51.0 . F=180.667, p<0.001, d f=6$, respectively). The CGS15943 promoted cardiomyocytes apoptosis compared with the ticagrelor group (52.0 $06.8 /$ field in CGS15943 group vs $20.1 \pm 2.3 /$ field in $50 \mathrm{mg} / \mathrm{kg}$, mean difference: 31.3, $\mathrm{F}=180.667, p<0.001, \mathrm{df}=6$ ) (Figure 2).

The effect of ticagrelor administration in cardiac function

In the sepsis group, the LVEF and LVFS were significantly lower than in the control and sham groups (LVEF: $51.9 \pm 2.8 \%$ vs $70.2 \pm 4.1 \%$ in control, mean difference: $-15.1, F=45.272, p<0.001, d f=6 ; 51.9 \pm 2.8 \%$ vs $70.4 \pm 3.6 \%$ in sham, mean difference: $-16.9, F=45.272, p<0.001, d f=6$, respectively; LVFS: $26.0 \pm 2.8 \%$ vs $41.4 \pm 2.5 \%$ in control, mean difference: $-14.7, \mathrm{~F}=12.940, p=0.001, \mathrm{df}=6 ; 26.0 \pm 2.8 \%$ vs $42.8 \pm 1.2 \%$ in sham, mean difference: $-16.9, F=12.940$, $p<0.001, \mathrm{df}=6$, respectively). Ticagrelor $10 \mathrm{mg} / \mathrm{kg}$ (LVEF: $57.4 \pm 3.7 \%$ vs sepsis, mean difference: $-3.3, \mathrm{~F}=45.272$, $p=0.897$, df $=6$; LVFS: $30.0 \pm 1.9 \%$ vs sepsis, mean difference: $4.8, \mathrm{~F}=12.940, p=0.907, \mathrm{df}=6$, respectively), $25 \mathrm{mg} / \mathrm{kg}$ (LVEF: $60.9 \pm 2.6 \%$ vs sepsis, mean difference: $6.5, F=45.272$, $p=0.032, \mathrm{df}=6$; LVFS: $32.2 \pm 2.0 \%$ vs sepsis, mean difference: $5.5, \mathrm{~F}=12.940, p=0.954, \mathrm{df}=6$, respectively) and $50 \mathrm{mg} / \mathrm{kg}$ LVEF: $68.2 \pm 2.2 \%$ vs sepsis, mean difference: $14.5, F=45.272$, $p<0.001, \mathrm{df}=6$; LVFS: $37.3 \pm 3.1 \%$ vs sepsis, mean difference: 13.1, $\mathrm{F}=12.940, p=0.003, \mathrm{df}=6$, respectively) protected cardiac function in sepsis and dependent on dose of drug. The CGS15943 inhibited the protecting effect of ticagrelor LVEF: $59.8 \pm 3.2 \%$ vs $50 \mathrm{mg} / \mathrm{kg}$, mean difference: $-9.6, \mathrm{~F}=45.272, p=0.001, \mathrm{df}=6 ; \mathrm{LVFS}: 31.6 \pm 3.4 \%$ vs $50 \mathrm{mg} / \mathrm{kg}$, mean difference: $-8.6, \mathrm{~F}=12.940, p=0.044, \mathrm{df}=6$, respectively). Further, the LVIDd and LVIDs in ticagrelor-treated mice were significantly lower than those in the sepsis group (no ticagrelor treatment). However, the LVIDd and LVIDs in the CGS15943 group were significantly higher than in the ticagrelor groups (Figure 3, Table 1).

\section{Plasma and myocardial tissue IL-6 and TNF- $\alpha$}

The plasma concentration of IL- 6 was higher in the sepsis group than that in the control and sham $(670.0 \pm 81.9 \mathrm{pg} / \mathrm{mL}$ vs $21.1 \pm 4.2 \mathrm{pg} / \mathrm{mL}$ in control, mean difference: $648.9, \mathrm{~F}=103.336, p<0.001, \mathrm{df}=6 ; 670.0 \pm 81.9 \mathrm{pg} /$ 
FIGURE 2.

EFFECT OF TICAGRELOR AND ANTAGONISTS ON CARDIOMYOCYTE APOPTOSIS.

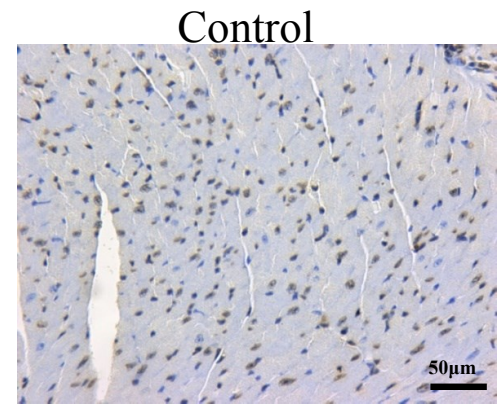

Ticagrelor $10 \mathrm{mg} / \mathrm{kg}$

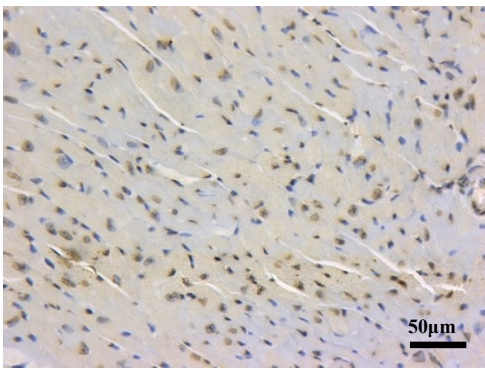

Ticagrelor $50 \mathrm{mg} / \mathrm{kg}$ $+\mathrm{CGS} 1594310 \mathrm{mg} / \mathrm{kg}$

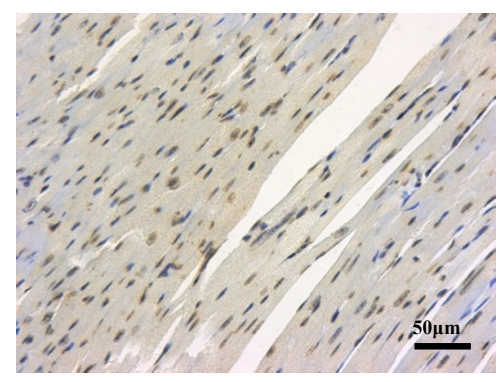

Sham

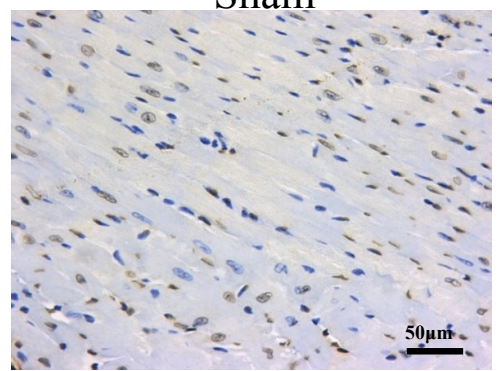

Ticagrelor $25 \mathrm{mg} / \mathrm{kg}$
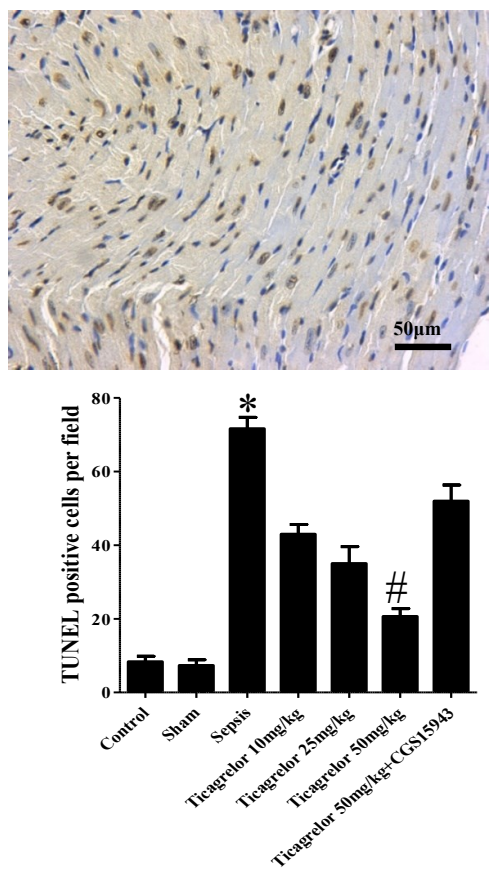

Sepsis

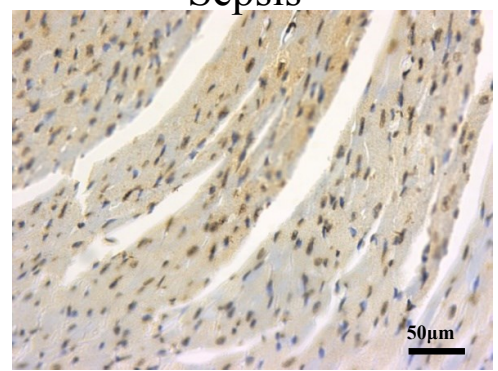

Ticagrelor $50 \mathrm{mg} / \mathrm{kg}$

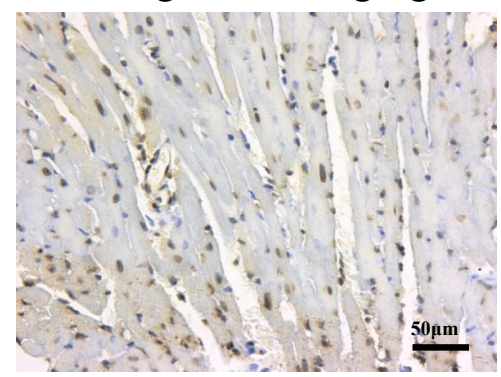

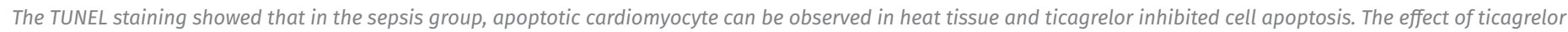

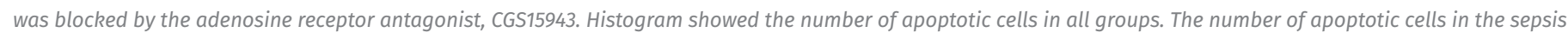

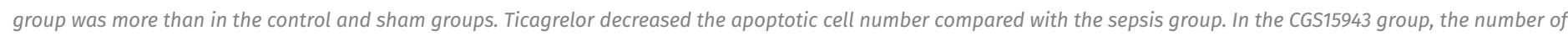
apoptotic cells were increased compared with ticagrelor groups ( $n=5$ for each group, * $p<0.001$ vs control and sham, \#p<0.001 vs sepsis; magnification: $400 X)$.

TABLE 1.

EFFECT OF TICAGRELOR ON PHYSIOLOGICAL PARAMETERS AND CARDIAC FUNCTION IN MOUSE MODEL OF SEPSIS

\begin{tabular}{|c|c|c|c|c|c|c|c|}
\hline & Control & Sham & Sepsis & $\begin{array}{l}\text { Ticagrelor } \\
10 \mathrm{mg} / \mathrm{kg}\end{array}$ & $\begin{array}{l}\text { Ticagrelor } \\
25 \mathrm{mg} / \mathrm{kg}\end{array}$ & $\begin{array}{l}\text { Ticagrelor } \\
50 \mathrm{mg} / \mathrm{kg}\end{array}$ & $\begin{array}{l}\text { Ticagrelor } \\
50 \mathrm{mg} / \mathrm{kg} \\
\text { CGS15943 }\end{array}$ \\
\hline LVEF, \% & $70.2 \pm 4.1$ & $70.4 \pm 3.6$ & $51.9 \pm 2.8$ & $57.4 \pm 3.7$ & $60.9 \pm 2.6^{+}$ & $68.2 \pm 2.2^{\dagger}$ & $59.8 \pm 3.2^{\ddagger}$ \\
\hline LVFS, \% & $41.1 \pm 2.5$ & $42.8 \pm 1.2$ & $26.0 \pm 2.8$ & $30.0 \pm 1.9$ & $32.2 \pm 2.0^{+}$ & $37.3 \pm 3.1^{+}$ & $31.6 \pm 3.4^{\ddagger}$ \\
\hline LVIDd, mm & $3.92 \pm 0.05$ & $3.89 \pm 0.07$ & $3.75 \pm 0.06$ & $4.45 \pm 0.03$ & $4.04 \pm 0.04$ & $3.67 \pm 0.05$ & $4.44 \pm 0.01$ \\
\hline LVIDs, mm & $2.39 \pm 0.09$ & $2.22 \pm 0.02$ & $2.78 \pm 0.12$ & $3.12 \pm 0.03$ & $2.74 \pm 0.07$ & $2.30 \pm 0.03$ & $.04 \pm 0.08$ \\
\hline
\end{tabular}

* CGS15943, adenosine-receptor antagonist; $+p<0.05$ vs sepsis; $\neq p<0.05$ vs ticagrelor $50 \mathrm{mg} / \mathrm{kg}$

Abbreviations: LVIDd, left ventricular internal dimension-end-diastolic; LVIDs, left ventricular internal dimension-end-systolic; LVEF, left ventricular ejection fraction; LVFS, left ventricular filling 
FIGURE 3.

EFFECT OF TICAGRELOR AND ANTAGONISTS ON CARDIAC FUNCTION.

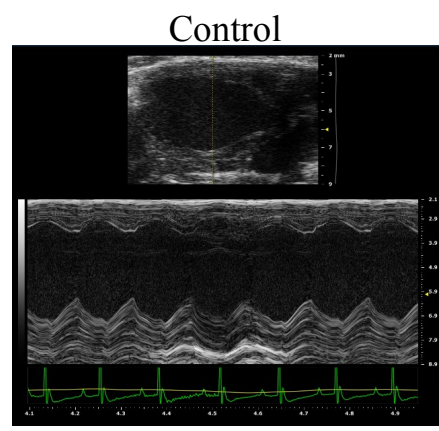

Ticagrelor $25 \mathrm{mg} / \mathrm{kg}$

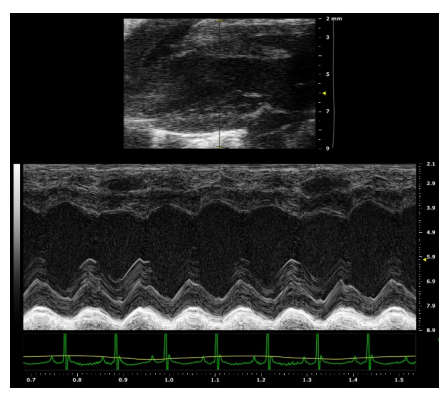

Sham

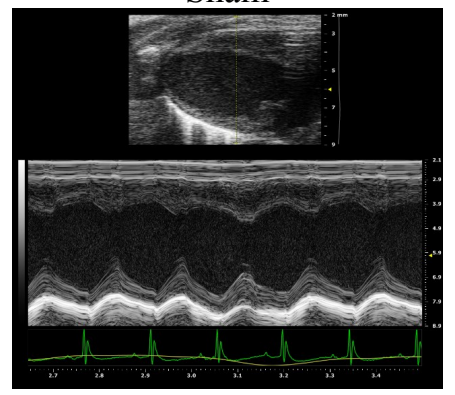

Ticagrelor $50 \mathrm{mg} / \mathrm{kg}$

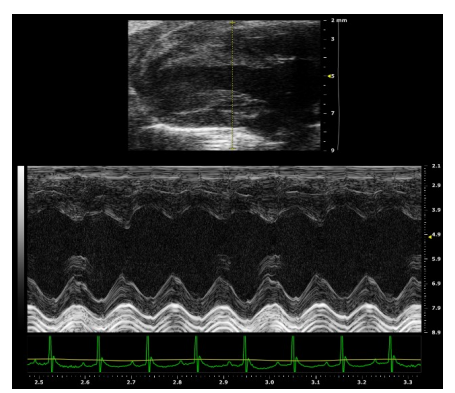

Sepsis

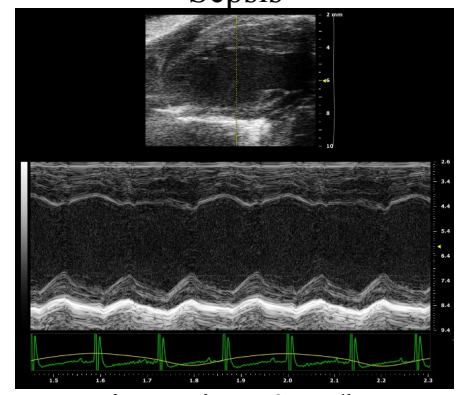

Ticagrelor $50 \mathrm{mg} / \mathrm{kg}$

$+\mathrm{CGS} 1594310 \mathrm{mg} / \mathrm{kg}$

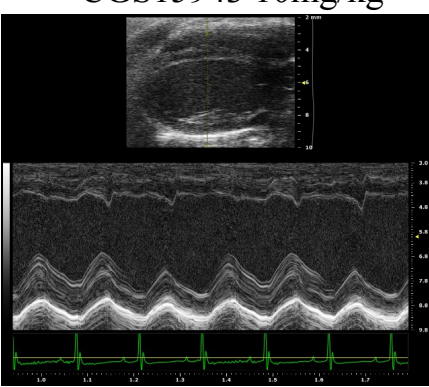

Ticagrelor $10 \mathrm{mg} / \mathrm{kg}$

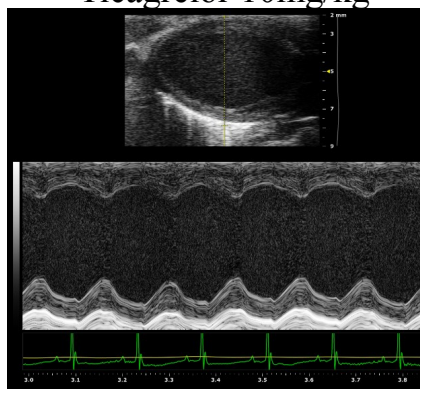

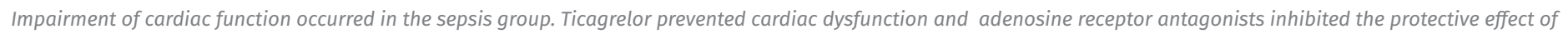

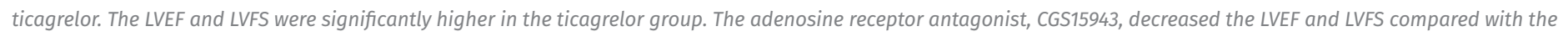
ticagrelor groups ( $n=5$ for each group).

$\mathrm{mL}$ vs $31.9 \pm 3.2 \mathrm{pg} / \mathrm{mL}$ in sham, mean difference: 648.1, $\mathrm{F}=103.336, p<0.001, \mathrm{df}=6$, respectively). Ticagrelor $10 \mathrm{mg} /$ $\mathrm{kg}(486.3 \pm 55.0 \mathrm{pg} / \mathrm{mL}), 25 \mathrm{mg} / \mathrm{kg}(310.0 \pm 10.0 \mathrm{pg} / \mathrm{mL})$ and $50 \mathrm{mg} / \mathrm{kg}(133.7 \pm 41.5 \mathrm{pg} / \mathrm{mL})$ decreased the plasma level of IL- 6 compared to sepsis group (10mg/ kg vs sepsis, mean difference: $-183.7, \mathrm{~F}=103.336, p=0.003$, df=6; $25 \mathrm{mg} / \mathrm{kg}$ vs sepsis, mean difference: $-360.0, \mathrm{~F}=103.336$, $\mathrm{p}<0.001, \mathrm{df}=6 ; 50 \mathrm{mg} / \mathrm{kg}$ vs sepsis, mean difference: $-536.3, \mathrm{~F}=103.336, p<0.001, \mathrm{df}=6$, respectively). CGS15943 increased plasma level compared to ticagrelor $50 \mathrm{mg} /$ $\mathrm{kg}(52.3 \pm 6.2 \mathrm{pg} / \mathrm{mL}$ vs $19.3 \pm 2.7 \mathrm{pg} / \mathrm{mL}$, mean difference: 320.0, $\mathrm{F}=103.336, p<0.001, \mathrm{df}=6)$. As similar with IL-6, ticagrelor $10 \mathrm{mg} / \mathrm{kg}(343.7 \pm 21.2 \mathrm{pg} / \mathrm{mL}), 25 \mathrm{mg} / \mathrm{kg}(249.0 \pm 8.5$ $\mathrm{pg} / \mathrm{mL})$ and $50 \mathrm{mg} / \mathrm{kg}(144.0 \pm 9.1 \mathrm{pg} / \mathrm{mL})$ decreased the plasma level of TNF- $\alpha$ compared to sepsis group $(436.7 \pm 37.9 \mathrm{pg} / \mathrm{mL})(10 \mathrm{mg} / \mathrm{kg}$ vs sepsis, mean difference: -93.0, $\mathrm{F}=163.095, p=0.002, \mathrm{df}=6 ; 25 \mathrm{mg} / \mathrm{kg}$ vs sepsis, mean difference: $-187.7, F=163.095, p<0.001, d f=6 ; 50 \mathrm{mg} / \mathrm{kg}$ vs sepsis, mean difference: $-292.7, \mathrm{~F}=163.095, p<0.001, \mathrm{df}=6$, respectively). The CGS15943 significantly inhibited the effect of ticagrelor $50 \mathrm{mg} / \mathrm{kg}(281.3 \pm 9.1 \mathrm{pg} / \mathrm{mL}$ vs $144.0 \pm 31.4$ $\mathrm{pg} / \mathrm{mL}$, mean difference: 137.3, $\mathrm{F}=163.095, p<0.001, \mathrm{df}=6$ ) (Figure 4).

The RT-PCR showed that the expression of IL-6 and TNF- $\alpha$ was significantly higher in the sepsis group than that in the myocardial tissue in the control and sham group. Ticagrelor decreased the IL- 6 and TNF- $\alpha$ levels and $50 \mathrm{mg} / \mathrm{kg}$ exerted the maximum protecting effect. Adenosine receptor blocking increased the tissue levels of IL- 6 and TNF- $\alpha$ compared with ticagrelor $50 \mathrm{mg} / \mathrm{kg}$ (IL6: $H=12.982, p=0.043, d f=6$; TNF- $\alpha$ : $H=15.556, p=0.016, d f=6$, respectively) (Figure 4).

\section{Plasma concentration of adenosine}

The plasma concentration of adenosine was higher in the ticagrelor $50 \mathrm{mg} / \mathrm{kg}$ group than that in the other two ticagrelor groups. $(112.0 \pm 3.7 \mathrm{pg} / \mathrm{uL}$ in $50 \mathrm{mg} / \mathrm{kg}$ group vs $27.3 \pm 2.6 \mathrm{pg} / \mathrm{uL}$ in $10 \mathrm{mg} / \mathrm{kg}$ group, mean difference: 84.7, $\mathrm{F}=356.718, p<0.001, \mathrm{df}=6 ; 112.0 \pm 3.7 \mathrm{pg} / \mathrm{uL}$ in $50 \mathrm{mg} /$ $\mathrm{kg}$ group vs $57.0 \pm 3.1 \mathrm{pg} / \mathrm{uL}$ in $25 \mathrm{mg} / \mathrm{kg}$ group, mean difference: 55.0, $\mathrm{F}=356.718, p<0.001, \mathrm{df}=6$, respectively). In addition, plasma adenosine level in ticagrelor group were significantly higher than sepsis $(27.3 \pm 2.6 \mathrm{pg} / \mathrm{uL}$ in $10 \mathrm{mg} / \mathrm{kg}$ group vs $11.67 \pm 1.9 \mathrm{pg} / \mathrm{uL}$ in sepsis group, mean difference: $15.7, \mathrm{~F}=356.718, p=0.006, \mathrm{df}=6 ; 57.0 \pm 3.1 \mathrm{pg} / \mathrm{uL}$ in $25 \mathrm{mg} / \mathrm{kg}$ group vs $11.67 \pm 1.9 \mathrm{pg} / \mathrm{uL}$ in sepsis group, mean difference: $45.3, \mathrm{~F}=356.718, p<0.001$, df=6; $112.0 \pm 3.7 \mathrm{pg} /$ $\mathrm{uL}$ in $50 \mathrm{mg} / \mathrm{kg}$ group vs $11.67 \pm 1.9 \mathrm{pg} / \mathrm{uL}$ in sepsis group, mean difference: 100.3, $F=356.718, p<0.001$, df=6, respectively). The CGS15943 did not decreased the level of ad- 
FIGURE 4.

EFFECT OF TICAGRELOR AND ANTAGONISTS ON PLASMA LEVELS OF IL-6, TNF- $\alpha$, ADENOSINE AND TISSUE LEVEL OF IL-6 AND TNF- $\alpha$.
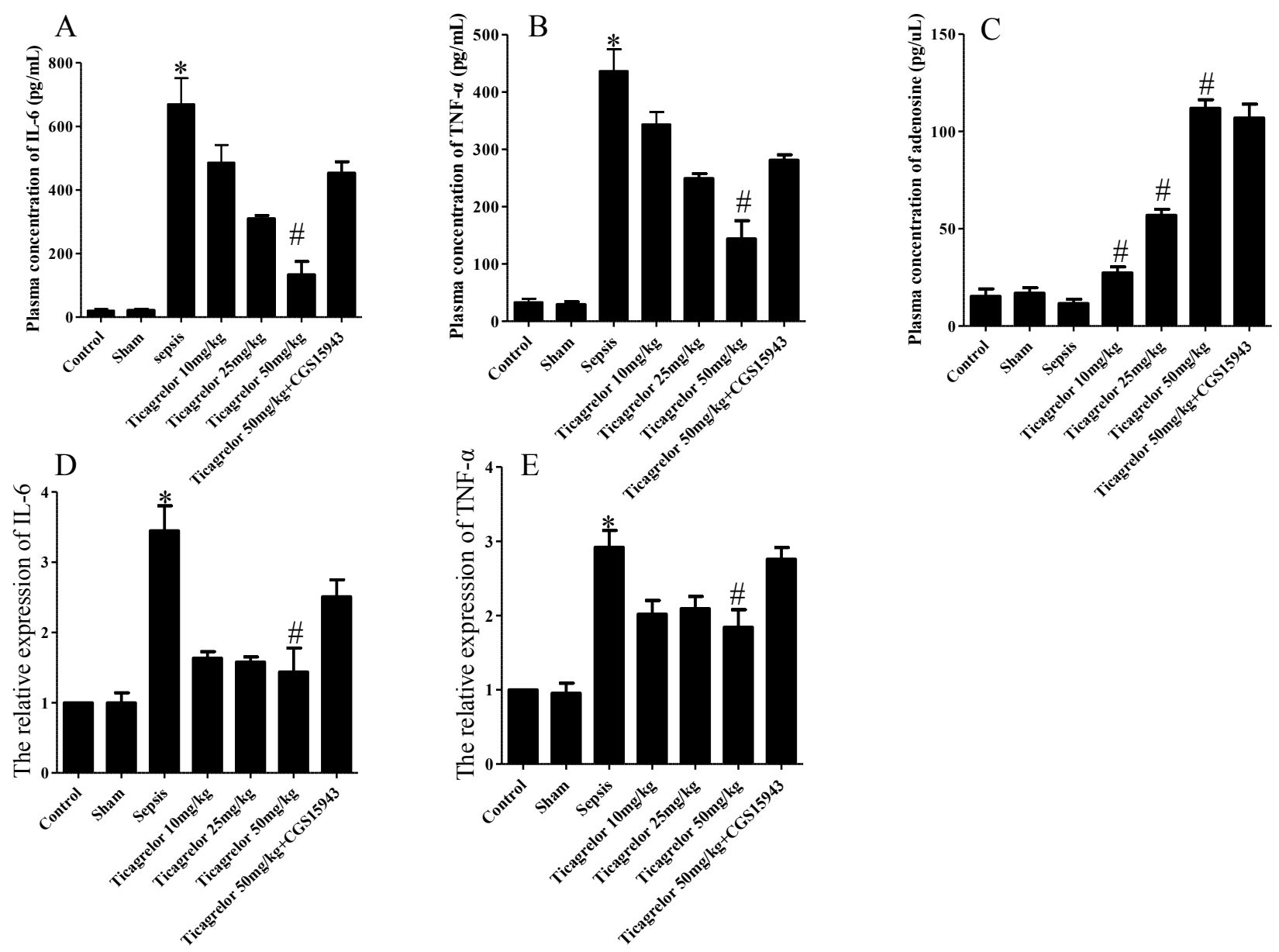

A) Plasma levels of IL-6 in all groups. In the sepsis group, the plasma level of IL-6 was higher than in the control and sham groups. Ticagrelor decreased the plasma level of IL-6, and CGS15943 increased the IL-6 level in plasma. B) Plasma levels of TNF- $\alpha$ in all groups. Similar to IL-6, the plasma level of TNF- $\alpha$ in the sepsis group was higher than in the control and sham groups. Ticagrelor decreased the plasma level of TNF- $\alpha$, and CGS15943 increased the plasma level of TNF- $\alpha$. C) Plasma levels of adenosine in all groups. Ticagrelor-treated groups had a high plasma level of adenosine compared with the sepsis group. The adenosine receptor antagonist, CGS15943, did not decrease the plasma level of adenosine. D) Tissue expression of IL-6. In the sepsis group, the myocardial tissue expression of IL-6 was higher than the control and sham. Ticagrelor decreased the tissue level of IL-6 compared with sepsis and CGS15943 increased the IL-6 level compared with the ticagrelor groups. E) Tissue expression of TNF- $\alpha$. In the sepsis group, the myocardial tissue expression of TNF- $\alpha$ was higher than in the control and sham groups. Ticagrelor decreased the tissue level of TNF- $\alpha$ compared with the sepsis group, and CGS15943 increased the tissue level of TNF- $\alpha$ level compared with the ticagrelor groups ( $n=5$ for each group, ${ }^{*}<0.05$ vs control and sham groups, \# $p<0.05$ vs sepsis).

enosine (107.0 $\pm 5.2 \mathrm{pg} / \mathrm{uL}$ in CGS15943 group vs $112.0 \pm 3.7$ $\mathrm{pg} / \mathrm{uL}$ in the ticagrelor $50 \mathrm{mg} / \mathrm{kg}$ group, mean difference: $-5.0, \mathrm{~F}=356.718, p=0.935, \mathrm{df}=6$ ) (Figure 4).

Effect of ticagrelor administration in the survival rate of sepsis mice

As shown in Figure 5, ticagrelor significantly reduced the mortality of sepsis mice and CGS15943 blocked the protective effect of ticagrelor (Chi-square: 41.66, $p<0.001$, $d f=6)$.
Ticagrelor regulated the adenosine receptor-dependent PI3K/AKT/mTOR signal pathway

In the sepsis group, the phosphorylation of AKT and mTOR was inhibited in myocardial tissue. Ticagrelor 50 $\mathrm{mg} / \mathrm{kg}$ significantly activated the phosphorylation of AKT and mTOR compared with sepsis; however, ticagrelor 10 $\mathrm{mg} / \mathrm{kg}$ and $25 \mathrm{mg} / \mathrm{kg}$ did not promote the activation of AKT and mTOR. Adenosine receptor antagonists blocked the activation of AKT and mTOR (AKT: $\mathrm{H}=10.699, p=0.941$, $\mathrm{df}=6$; mTOR: $\mathrm{H}=11.234, p=0.953, \mathrm{df}=6$; P-AKT: $\mathrm{H}=17.713$, $p=0.007, \mathrm{df}=6$; P-mTOR: $\mathrm{H}=19.507, p=0.003, \mathrm{df}=6$, respectively) (Figure 6). 
FIGURE 5.

\section{EFFECT OF TICAGRELOR AND ANTAGONISTS ON THE SURVIVAL OF SEPSIS MICE.}

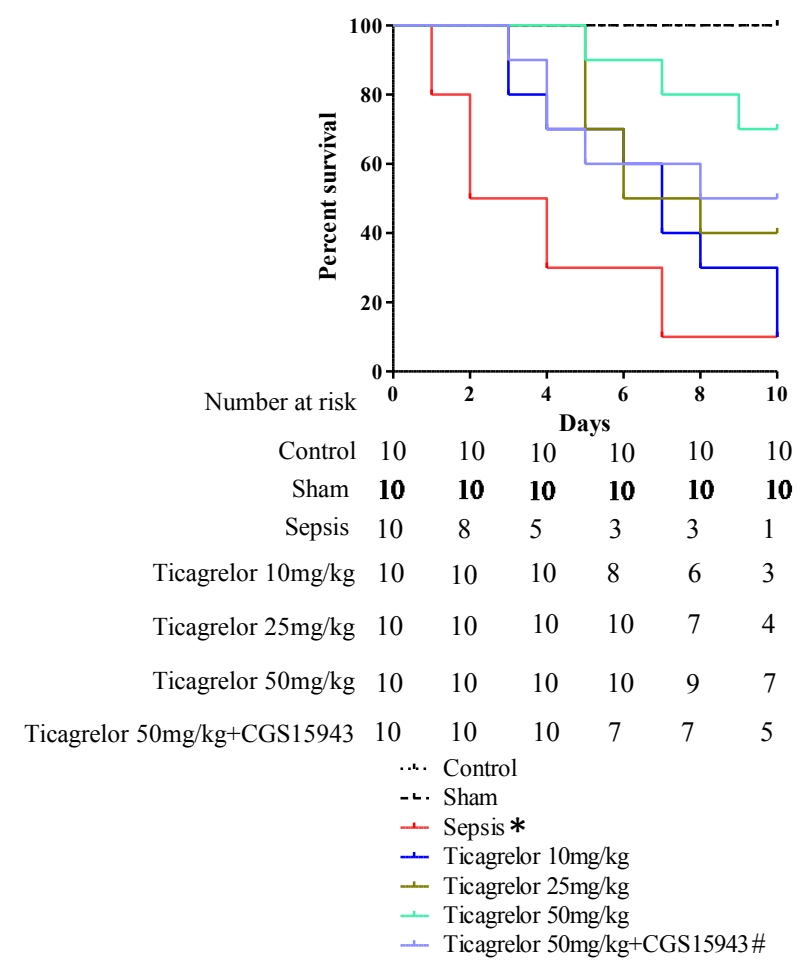

The survival curve showed that ticagrelor reduced the mortality of sepsis mice. The adenosine receptor, CGS15943, increased the mortality of sepsis mice compared with the ticagrelor groups ( $n=10$ for each group, *sepsis vs ticagrelor 10, 25 and $50 \mathrm{mg} / \mathrm{kg}$ groups, $p<0.001$; \#ticagrelor $50 \mathrm{mg} / \mathrm{kg}+$ CGS15943 vs ticagrelor $50 \mathrm{mg} / \mathrm{kg}$ groups, $p<0.001$ ).

\section{DISCUSSION}

In this study, we found that ticagrelor decreased the inflammatory level in sepsis-induced myocardial injury, and that ticagrelor alleviated sepsis-induced myocardial injury via a dose-dependent and adenosine-dependent pathway.

Anti-platelet therapy is the basic treatment in cardiovascular diseases such as atherosclerosis and myocardial infarction. Ticagrelor, which blocks the prothrombotic effects of platelets, showed an obvious clinical benefit in the treatment of coronary artery disease and with percutaneous coronary intervention. Prolonged ticagrelor treatment has been shown to improve the prognosis of patients with cardiovascular disease [16]. A previous study suggested that ticagrelor is associated with reduced inflammation on follow-up after percutaneous coronary intervention, suggesting that anti-inflammatory effects might play a role in the clinical benefit observed with antiplatelet therapy in ST-elevated myocardial infarction [17]. In infectious diseases, ticagrelor prevented multi-organ dysfunction, especially in gram-positive cocci induced sepsis [18]. Sepsis-induced myocardial injury is common in intensive care units and leads to high mortality in sepsis patients. However, whether ticagrelor alleviates sepsis-induced myocardial injury had not been studied. Our research revealed that ticagrelor inhibited the systemic inflammatory reaction and alleviated the myocardial injury in a mouse sepsis model.

Ticagrelor has been found to inhibit platelet aggregation via platelet $\mathrm{P} 2 \mathrm{Y} 12$ receptor blocking to reduce the severity of cardiovascular events in humans. A randomized clinical trial showed that myocardial infarct size was significantly smaller in the ticagrelor group than in the clopidogrel group, although the detailed mechanism was not studied further [19]. Ticagrelor was also showed to limit the cellular adenosine reuptake and increase the plasma concentration of adenosine. Previous studies have indicated a adenosine-mediated cardiac protecting effect. In non-ST elevated myocardial infarction patients, ticagrelor protected the myocardium via increased plasma levels of adenosine [20]. In the mouse myocardial infarction model, ticagrelor significantly reduced the infarct size via an adenosine-dependent mechanism [12]. An adenosine-associated endogenous vasodilating effect may partly explain the protecting effect of adenosine. The effect was dependent on the A2a receptor of adenosine [21]. However, adenosine can also directly reduce the apoptosis of cardiomyocytes in an ischemia-reperfusion model [22]. Adenosine has four receptors, A1, A2a, A2b and A3, which show different biological effects. The $A 1$ receptor is expressed in the heart and, binding to adenosine, can decrease the myocardial oxygen consumption and the generation of oxygen radicals. The A2a receptor is a widely studied receptor and is a key molecule that has been found to regulate the cardiac-protecting effect of adenosine [23]. A previous study also indicated that in sepsis, adenosine, and its A2a receptor agonist, served as signal transducer factors of the CD39/CD73/adenosine pathway, accelerating the production of adenosine, which can regulate the immune reaction [24]. However, whether the other two receptors exert cardiac protecting effects is still under debate. Furthermore, the signalling pathways, which regulate the effect of adenosine, need further study. In this present study, we hypothesized that oral administration of ticagrelor increases the plasma level of adenosine. We also found that adenosine-receptor antagonist, CGS15943, which can block the A2a and A1 receptors, reversed the myocardium-protecting effect of ticagrelor. Further, CGS15943 blocked the activation of the downstream signal protein, PI3K.

The protein, $\mathrm{PI} 3 \mathrm{~K}$, is a classic signal molecule that regulates cell proliferation, senescence and apoptosis [25]. Adenosine can efficiently activate the PI3K signal pathway that enables this protecting effect $[26,27]$. In a myocardial cell line, activation of adenosine receptors 
FIGURE 6.

EFFECT OF TICAGRELOR AND ANTAGONISTS ON THE EXPRESSION OF SIGNAL PROTEIN EXPRESSION IN HEART TISSUE.

A

\begin{tabular}{|c|c|c|c|c|c|c|}
\hline & Shat & Sepsis & $\begin{array}{r}\text { Ticagrelor } \\
10 \mathrm{mg} / \mathrm{kg}\end{array}$ & $\begin{array}{r}\text { Ticagrelor } \\
25 \mathrm{mg} / \mathrm{kg}\end{array}$ & $\begin{array}{r}\text { Ticagrelor } \\
50 \mathrm{mg} / \mathrm{kg}\end{array}$ & $\begin{array}{c}\text { Ticagrelor } 50 \mathrm{mg} / \mathrm{kg} \\
+ \text { CGS } 15943\end{array}$ \\
\hline
\end{tabular}

Phospho-AKT

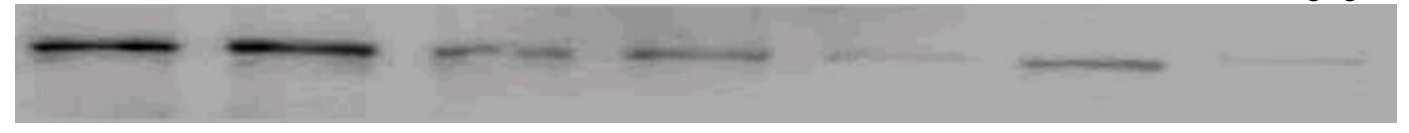

AKT

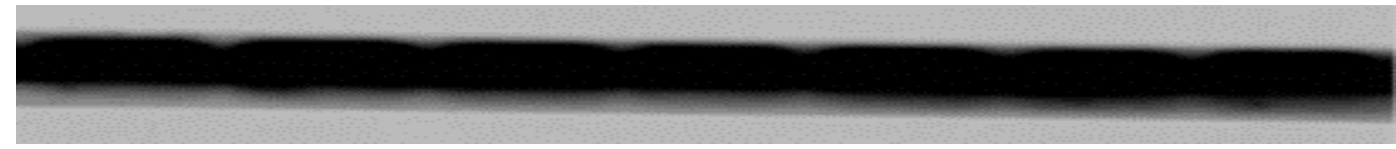

Phospho-mTOR

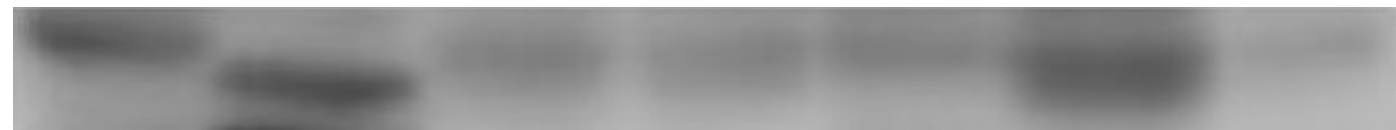

mTOR

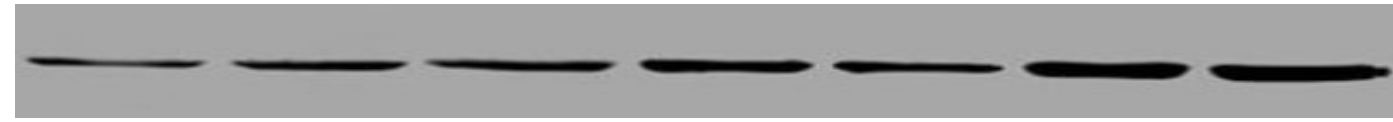

GAPDH

B
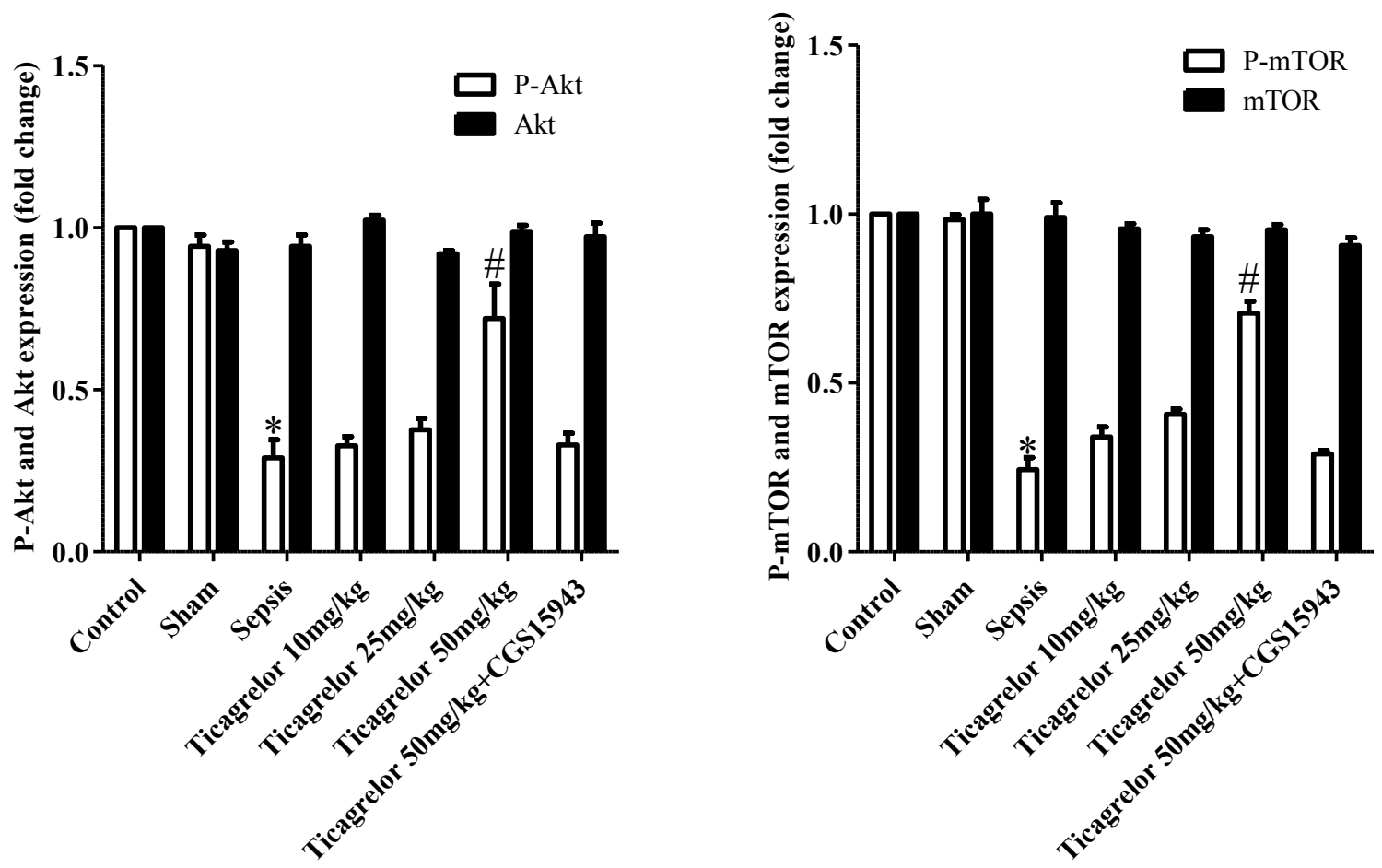

A) Representative band showed that, in sepsis, phosphorylation of AKT and mTOR was inhibited and that ticagrelor increased the phosphorylated of AKT and mTOR. The CGS15943 suppressed the activation of AKT and mTOR. B) Histogram showing densitometry quantitation of protein expression levels, shown as fold changes ( $n=5$ for each group, ${ }^{*} p<0.05$ vs control and sham, \# $p<0.05$ vs sepsis). 
attenuates high glucose-induced apoptosis via PI3K/ Akt signalling [28]. This research indicated that the PI3K is the key downstream signal protein of adenosine. Our data also suggested that ticagrelor promoted the activation of the PI3K/Akt pathway and that CGS15943 blocked the phosphorylation of Akt. This research further indicated that in sepsis-induced myocardial injury, ticagrelor promoted the activation of PI3K/Akt via an adenosine-dependent mechanism.

The PI3K/AKT/mTOR pathway plays a key role in many diseases and organ disorders, especially in cancer [29, 30], and the relationship between mTOR and organ injury is being studied by a number of researchers. mTOR is a pivotal molecule in inflammation and immune regulation. However, mTOR exerts different effects in different diseases and microenvironments. A previous study revealed that deletion of the mTOR mediator resulted in prolonged life via the inhibition of cell reproductive aging. This indicated that mTOR blocked the inhibited cell replication [31]. In cell research, mTOR inhibitor, rapamycin, was found to have promoted cellular senescence. Additionally, mTOR blocking has protective effects against insulin resistance and Alzheimer disease $[32,33]$. The role of mTOR in different diseases, and even in different stages of a single disease, is controversy. In LPS-induced inflammation, the activation of mTOR is associated with vasodilator and pro-inflammatory mediator formation [34]. Some researchers have suggested that the key role of mTOR is to adjust the balance of pro-inflammatory and anti-inflammatory responses to further regulate the immune system [35]. In addition, mTOR signal pathway was found to promote cell proliferation; strongly indicating that activation of mTOR may be beneficial in stress or inflammatory conditions $[25,36]$. In the present research, we found that ticagrelor promoted the activation of mTOR via phosphorylated of Akt and further lead to apoptosis of cardiomyocytes. The $\mathrm{PI3K} / \mathrm{AKT} / \mathrm{mTOR}$ pathway has been widely researched in the cardiovascular system. Activating of the PI3K/AKT/ mTOR pathway prevented heart injury triggered by various stress factors [37,38]. In sepsis-induced myocardial injury, AKT/mTOR signalling prevented cardiac dysfunction via mitochondrial autophagy [39]. Our data showed that ticagrelor-triggered activation of PI3K/AKT/mTOR signalling inhibited myocardial injury and prevented the cardiac dysfunction in sepsis.

This study had some limitations. Firstly, the CLP sepsis model may not reproduce the pathological progression of sepsis in clinical practice and the mechanisms of myocardial injury may be different. Secondly, the technique of deletion of mTOR was not used in the sepsis model, so the role of mTOR needs to be further studied to identify the upstream and downstream signals.

\section{CONCLUSION}

Ticagrelor inhibited cardiomyocyte apoptosis in sepsis-induced myocardial injury via an adenosine-dependent PI3K/AKT/mTOR signal pathway.

\section{FINANCIAL SUPPORT}

This work was supported by the National Natural Science Foundation of China (81700265 to Cong Fu and 81702092 to Yuhan Cao).

\section{REFERENCES}

1. Singer $M$, Deutschman CS, Seymour CW, Shankar-Hari M, Annane D, Bauer M, Bellomo R, Bernard GR, Chiche JD, Coopersmith CM, Hotchkiss RS, Levy MM, Marshall JC, Martin GS, Opal SM, Rubenfeld GD, van der Poll T, Vincent JL and Angus DC. The Third International Consensus Definitions for Sepsis and Septic Shock (Sepsis-3). JAMA. 2016; 315:801810.

2. Gamkrelidze M, Intskirveli N, Vardosanidze K, Goliadze L, Chikhladze K and Ratiani L. Myocardial dysfunction during septic shock (review). Georgian Med News. 201440-46.

3. Sexton TR, Zhang G, Macaulay TE, Callahan LA, Charnigo R, Vsevolozhskaya OA, Li Z and Smyth S. Ticagrelor Reduces Thromboinflammatory Markers in Patients With Pneumonia. JACC Basic Transl Sci. 2018; 3:435-449.

4. Li X, Li Y, Shen K, Li H and Bai J. The protective effect of ticagrelor on renal function in a mouse model of sepsis-induced acute kidney injury. Platelets. 2019; 30:199-205.

5. Gurbel PA, Bliden KP, Butler K, Tantry US, Gesheff T, Wei C, Teng R, Antonino MJ, Patil SB, Karunakaran A, Kereiakes DJ, Parris C, Purdy D, Wilson V, Ledley GS and Storey RF. Randomized double-blind assessment of the ONSET and OFFSET of the antiplatelet effects of ticagrelor versus clopidogrel in patients with stable coronary artery disease: the ONSET/OFFSET study. Circulation. 2009; 120:2577-2585.

6. Ortega-Paz L, Brugaletta S, Ariotti S, Akkerhuis KM, Karagiannis A, Windecker S and Valgimigli M. Adenosine and Ticagrelor Plasma Levels in Patients With and Without Ticagrelor-Related Dyspnea. Circulation. 2018; 138:646-648.

7. Nylander S, Femia EA, Scavone M, Berntsson P, Asztely AK, Nelander K, Lofgren L, Nilsson RG and Cattaneo M. Ticagrelor inhibits human platelet aggregation via adenosine in addition to P2Y12 antagonism. J Thromb Haemost. 2013; 11:1867-1876.

8. Alexopoulos D, Moulias A, Koutsogiannis N, Xanthopoulou I, Kakkavas A, Mavronasiou E, Davlouros P and Hahalis G. Differential effect of ticagrelor versus prasugrel on coronary blood flow velocity in patients with non-ST-elevation acute coronary syndrome undergoing percutaneous coronary intervention: an exploratory study. Circ Cardiovasc Interv. 2013; 6:277-283. 
9. Armstrong D, Summers C, Ewart L, Nylander S, Sidaway JE and van Giezen JJ. Characterization of the adenosine pharmacology of ticagrelor reveals therapeutically relevant inhibition of equilibrative nucleoside transporter 1. J Cardiovasc Pharmacol Ther. 2014; 19:209-219.

10. Yellon DM, Baxter GF, Garcia-Dorado D, Heusch G and Sumeray MS. Ischaemic preconditioning: present position and future directions. Cardiovasc Res. 1998; 37:21-33.

11. Spiller F, Costa C, Souto FO, Vinchi F, Mestriner FL, Laure HJ, Alves-Filho JC, Freitas A, Rosa JC, Ferreira SH, Altruda F, Hirsch E, Greene LJ, Tolosano E and Cunha FQ. Inhibition of neutrophil migration by hemopexin leads to increased mortality due to sepsis in mice. Am J Respir Crit Care Med. 2011; 183:922-931.

12. Nanhwan MK, Ling S, Kodakandla M, Nylander S, Ye Y and Birnbaum Y. Chronic treatment with ticagrelor limits myocardial infarct size: an adenosine and cyclooxygenase-2-dependent effect. Arterioscler Thromb Vasc Biol. 2014; 34:2078-2085.

13. Sheng Z, Yao Y, Li Y, Yan F, Huang J and Ma G. Bradykinin preconditioning improves therapeutic potential of human endothelial progenitor cells in infarcted myocardium. Plos One. 2013; 8:e81505.

14. Weber B, Mendler MR, Lackner I, Pressmar J, Haffner-Luntzer M, Hofler S, Braun CK, Hummler H, Schwarz $\mathrm{S}$ and Kalbitz $\mathrm{M}$. Tissue damage in the heart after cardiac arrest induced by asphyxia and hemorrhage in newborn pigs. Pediatr Res. 2019; 86:709-718.

15. Braun CK, Kalbitz M, Halbgebauer R, Eisele P, Messerer D, Weckbach S, Schultze A, Braumuller S, Gebhard F and Huber-Lang MS. Early structural changes of the heart after experimental polytrauma and hemorrhagic shock. Plos One. 2017; 12:e187327.

16. Wallentin L, Becker RC, Budaj A, Cannon CP, Emanuelsson H, Held C, Horrow J, Husted S, James S, Katus H, Mahaffey KW, Scirica BM, Skene A, Steg PG, Storey RF, Harrington RA, Freij A and Thorsen M. Ticagrelor versus clopidogrel in patients with acute coronary syndromes. $N$ Engl J Med. 2009; 361:1045-1057.

17. Jiang Z, Zhang R, Sun M, Liu Q, Wang S, Wang W, Zhao Q, Zhang $\mathrm{H}$, Wang $\mathrm{Y}$, Hou J and Yu B. Effect of Clopidogrel vs Ticagrelor on Platelet Aggregation and Inflammation Markers After Percutaneous Coronary Intervention for ST-Elevation Myocardial Infarction. Can J Cardiol. 2018; 34:1606-1612.

18. Jean SS, Hsueh SC, Hwang JJ and Hsueh PR. Ticagrelor: A promising role in preventing multi-organ failure among patients with sepsis due to resistant gram-positive cocci. J Microbiol Immunol Infect. 2019; 52:513-515.

19. Kim EK, Park TK, Yang JH, Song YB, Choi JH, Choi SH, Chun WJ, Choe YH, Gwon HC and Hahn JY. Ticagrelor Versus Clopidogrel on Myocardial Infarct Size in Patients Undergoing Primary Percutaneous Coronary Intervention. J Am Coll Cardiol. 2017; 69:2098-2099.
20. Bonello L, Laine M, Kipson N, Mancini J, Helal O, Fromonot J, Gariboldi V, Condo J, Thuny F, Frere C, Camoin-Jau L, Paganelli F, Dignat-George F and Guieu R. Ticagrelor increases adenosine plasma concentration in patients with an acute coronary syndrome. J Am Coll Cardiol. 2014; 63:872-877.

21. Shryock JC and Belardinelli L. Adenosine and adenosine receptors in the cardiovascular system: biochemistry, physiology, and pharmacology. Am J Cardiol. 1997; 79:2-10.

22. Zhao ZQ, Budde JM, Morris C, Wang NP, Velez DA, Muraki S, Guyton RA and Vinten-Johansen J. Adenosine attenuates reperfusion-induced apoptotic cell death by modulating expression of Bcl-2 and Bax proteins. J Mol Cell Cardiol. 2001; 33:57-68.

23. Toufektsian MC, Yang Z, Prasad KM, Overbergh L, Ramos SI, Mathieu C, Linden J and French BA. Stimulation of A2A-adenosine receptors after myocardial infarction suppresses inflammatory activation and attenuates contractile dysfunction in the remote left ventricle. Am J Physiol Heart Circ Physiol. 2006; 290:H1410-H1418.

24. Bao R, Shui X, Hou J, Li J, Deng X, Zhu X and Yang T. Adenosine and the adenosine A2A receptor agonist, CGS21680, upregulate CD39 and CD73 expression through E2F-1 and CREB in regulatory $T$ cells isolated from septic mice. Int J Mol Med. 2016; 38:969-975.

25. Fu C, Cao Y, Li B, Xu R, Sun Y and Yao Y. Bradykinin protects cardiac c-kit positive cells from high-glucose-induced senescence through B2 receptor signaling pathway. J Cell Biochem. 2019.

26. Tian Y, Piras BA, Kron IL, French BA and Yang Z. Adenosine 2B Receptor Activation Reduces Myocardial Reperfusion Injury by Promoting Anti-Inflammatory Macrophages Differentiation via PI3K/Akt Pathway. Oxid Med Cell Longev. 2015; 2015:585297.

27. Huang X, Wu P, Huang F, Xu M, Chen M, Huang K, Li GP, Xu M, Yao $D$ and Wang $L$. Baicalin attenuates chronic hypoxia-induced pulmonary hypertension via adenosine A2A receptor-induced SDF-1/CXCR4/PI3K/AKT signaling. J Biomed Sci. 2017; 24:52.

28. Shen Y, Tang G, Gao P, Zhang B, Xiao H and Si LY. Activation of adenosine $A 2 b$ receptor attenuates high glucose-induced apoptosis in $\mathrm{H} 9 \mathrm{C} 2$ cells via PI3K/Akt signaling. In Vitro Cell Dev Biol Anim. 2018; 54:384-391.

29. Shi L, Wu Z, Miao J, Du S, Ai S, Xu E, Feng M, Song J and Guan W. Adenosine Interaction with Adenosine Receptor A2a Promotes Gastric Cancer Metastasis by Enhancing PI3KAKT-mTOR Signaling. Mol Biol Cell. 2019E19030136.

30. Dando I, Cordani M and Donadelli M. Mutant p53 and mTOR/PKM2 regulation in cancer cells. lubmb Life. 2016; 68:722-726.

31. Selman C and Withers DJ. Mammalian models of extended healthy lifespan. Philos Trans R Soc Lond B Biol Sci. 2011; 366:99-107.

32. Fontana L, Partridge $L$ and Longo VD. Extending healthy life span--from yeast to humans. Science. 2010; 328:321-326. 
33. Kapahi P, Chen D, Rogers AN, Katewa SD, Li PW, Thomas EL and Kockel L. With TOR, less is more: a key role for the conserved nutrient-sensing TOR pathway in aging. Cell Metab. 2010; 11:453-465.

34. Temiz-Resitoglu M, Kucukkavruk SP, Guden DS, Cecen P, Sari AN, Tunctan B, Gorur A, Tamer-Gumus L, Buharalioglu CK, Malik KU and Sahan-Firat S. Activation of mTOR/ IkappaB-alpha/NF-kappaB pathway contributes to LPS-induced hypotension and inflammation in rats. Eur J Pharmacol. 2017; 802:7-19.

35. Cobbold SP. The mTOR pathway and integrating immune regulation. Immunology. 2013; 140:391-398.

36. Wang Y, Chen J, Tang W, Zhang Y and Li X. Rapamycin inhibits the proliferation of endothelial cells in hemangioma by blocking the mTOR-FABP4 pathway. Biomed Pharmacother. 2017; 85:272-279.
37. Guan P, Sun ZM, Wang N, Zhou J, Luo LF, Zhao YS and Ji ES. Resveratrol prevents chronic intermittent hypoxia-induced cardiac hypertrophy by targeting the PI3K/AKT/mTOR pathway. Life Sci. 2019; 233:116748.

38. Ba L, Gao J, Chen Y, Qi H, Dong C, Pan H, Zhang Q, Shi P, Song C, Guan X, Cao Y and Sun H. Allicin attenuates pathological cardiac hypertrophy by inhibiting autophagy via activation of PI3K/Akt/mTOR and MAPK/ERK/mTOR signaling pathways. Phytomedicine. 2019; 58:152765.

39. Zhang E, Zhao X, Zhang L, Li N, Yan J, Tu K, Yan R, Hu J, Zhang M, Sun D and Hou L. Minocycline promotes cardiomyocyte mitochondrial autophagy and cardiomyocyte autophagy to prevent sepsis-induced cardiac dysfunction by Akt/mTOR signaling. Apoptosis. 2019; 24:369-381. 